\title{
Investigating Customer Feedback Channels in the Hotel Industry: the Case of Ho - Ghana
}

\author{
Helen Mavis Dah, Msc \\ Department of Hospitality \& Tourism Management, Ho Polytechnic, Ghana \\ Arnold Dumenya, B.Tech \\ Department of Mechanical Engineering, Ho Polytechnic, Ghana
}

doi: 10.19044/esj.2016.v12n26p353 URL:http://dx.doi.org/10.19044/esj.2016.v12n26p353

\begin{abstract}
Knowing what delight customers and satisfying them is highly critical for success in today's competitive business environment. In order to satisfy customers and to meet their expectations, hotels must be able to understand customers' needs and wants. Customer feedback provides invaluable information for organizations to re-orient their products and services. This study explores customer feedback channels that are used by hotels in Ho, Ghana and examines customers' perceptions on the effectiveness of the feedback channels. Also, customers' preferred channels were examined. Structured questionnaires were administered to 300 hotel guests at random. Out of the 300 questionnaires distributed, 171 were completed and used in the final analyses. Data was analyzed using SPSS version 22. The results revealed that suggestion box was mostly used by the hotels and guests perceived this channel as most effective among all other feedback channels. Also, guests preferred to provide feedback on one-on-one contact. The study concludes that developing effective customer feedback channels would motivate guests to tell the hotel management about their satisfaction or dissatisfaction on the hotel services and products. Guest contact staff should be well trained in handling customer feedback and to possess good communication skills.
\end{abstract}

Keywords: Customer feedback channels, Hotel Industry, Ho, Ghana

\section{Introduction}

The ultimate objectives of hotels are to exceed customer expectations, satisfy customers, and retain them to become loyal. Satisfying customers are essential to sustaining hotel business in a competitive environment. In order to satisfy customers and to meet their expectations, hotels must be able to understand customers' needs and wants. Customer feedback channel is an effective and inexpensive means to understand the insight of customers needs 
and wants (Heung, Kucukusta \& Ekiz, 2010). It guides and informs company's decision and influences its products in service delivery. Besides, it is essential for measuring customer satisfaction (Ciotti, 2013). It is imperative for hotel business to have a regular customer feedback to improve the service system, especially in today's business environment where customers are becoming more knowledgeable and demanding. Gilly \& Hanson (1985) opined that in today's business setting where competition is a challenge, considering customer satisfaction is essential for business sustainability. In other words, effective execution of customer feedback results in customer satisfaction, leading to customer retention.

According to Ofir \& Simonson (2001), the way companies handle customer feedback differentiates the successful ones from the unsuccessful ones. The success of any company lies in its ability to satisfy customers. The main idea behind having an effective system is to deal with problems encountered by customers. Research proposed various important outcomes of customer feedback management, these include assistance in performance assessment, facilitation of organizational learning (Babbar \& Koufteros, 2008), improvement of overall service quality (Wirtz et al., 2010), better decision making (Bitner et al., 1994), and generation of competitive advantage (Lusch et al., 2007). Really, customer feedback provides invaluable information for business of all types and sizes. Customer feedback provides benefits that enhance a company's Customer Relationship Management system. The effectiveness of CRM is directly tied to firms' ability to obtain clear customer feedback (Heung, Kucukusta \& Ekiz, 2010).

There are various channels of collecting feedback from customers in hotels. Making the right choice determines the success of the channel. Research has found a relationship between demographic characteristics and attitudes of customers' relating to complaint behavior. For instance; young and middle age group complain publicly than old customers (Heung \& Lam, 2003), younger, better educated, and higher income level groups complain more than others (Lam \& Tang, 2003). In the case of Sujithamrak \& Lam (2005) older, well- educated customers with higher income take private action to complain. Hence, developing systems to manage customer feedbacks, hotels have to assess the profile of its guests because demographic characteristics of the guests affect their choice of feedback channels. According to Fundin \& Bergman (2003), it is worth to have an orderly process for gathering feedback from customers. Knowing things that satisfy customers is crucial for the success of hospitality organizations (Cole, 2001). In order to utilize customer feedback and information effectively, hotels need systematic and functioning methods to gather, process and analyze data (Ackley, 2007) relating to customer feedback. Smith \& Jenner (1998) noted that in this technological advancement era, hotels would not improve if they still use 
conventional means like newsletters and telemarketing in communicating with their customers. Therefore to survive in this competitive environment, hoteliers should reduce their distribution costs by adopting new customer feedback channels.

The hotel industry in Ghana is growing at a fast rate. Therefore it is essential to understand how guests can provide feedback to the hotels about any service needs or problems. In light of the importance of customer feedback for hotels in Ghana and for those matter hotels in Ho, the present study aims to explore guests' evaluation of feedback channels in hotels. Specifically, the objectives of the study are; to identify the available customer feedback channels in hotels in the Ho Municipality, to examine customers' perceptions on the effectiveness of these feedback channels and to explore customer feedback channel guests prefer most.

\section{Literature Review}

\subsection{Customer feedback}

Feedback is a term used to describe the helpful information or criticism about prior action or behavior from an individual, communicated to another individual who can use the information to adjust and improve current and future actions and behaviors (Wyse, 2015). In this regards, customer feedback is the buyers' reaction to a company's products, services or policies. Further, customer feedback is a means of knowing whether customers are satisfied or dissatisfied with a company's product or service. It is an important element of quality management, especially in the service industry (Chase \& Hayes, 1991). Erickson \& Eckrich (2001) in their study defined customer feedback as customer communication regarding a product or a service. Berry \& Parasuraman, (1997) categorized customer feedback as either solicited or unsolicited. The authors explained solicited feedback is introduced by organizations by the usage of tools such as surveys and focus groups to receive feedback from customers (Sampson, 1998). Unsolicited customer feedback depends on the customers' own wish to communicate their experiences. Day \& Landon (1977) took a step further to distinguish between unsolicited customer feedback as, private and public communication. According to them, private communication is an interpersonal communication while public communication is addressed to the firm. Interpersonal communication of unsolicited customer feedback is manifested through word of mouth (Day \& Landon, 1977).

Obtaining feedback from customers regularly is necessary, particularly in an era where customers are becoming more knowledgeable, demanding and vocal (Pearson, 1976). Likewise, in a situation of fierce competition where customer retention is crucial, (Gilly \& Hansen, 1985) considering customer feedback is important to companies particularly hotels. Even though deletion 
of all troubles in a service encounter is unfeasible, the means by which organizations react to their customers' complaints distinguish the successful ones from the unsuccessful (Maxham, 2001; Ofir \& Simonson, 2001). According to Donovan \& Samler (1994) for any company to succeed depends on its ability to strive to fine-tune to identifying the needs and wants of customers, and this could be through gathering feedback from customers.

A study conducted by Fundin \& Borgman (2003) reported how feedback from dissatisfied customers is transmitted within organizations. The organizations that have a systematic process to handle customer issues have a good relationship with their customers. Organization's database structures assist the service personnel to compile information about customer claims. This demonstrates a firm's ability to resolve customer's complaints. In order to evaluate service level, organizations should monitor customer feedback collection (Donovan \& Samler, 1994; Graulich, 1991). The positive aspect of maintaining effective customer problems remains with the fact that, it promotes retention rates by word of mouth and improves performance. Gathering customer feedback serves as a catalyst to identifying customer's needs and want. This facilitates in designing strategies to meet customer expectations.

According to Hoffman \& Bateson (1997), communication between the client and the hotel is very necessary, and assessing your hotel performance is the initial step to meeting guest's satisfaction and increasing repeat visit. Based on this, Chisholm (2005) caution that, increasing customer number is crucial for service improvement and the dissatisfied customer can simply be noticed and quick actions taken. The use of feedback data to determine quality service, and identify suggestions for improvement has been recommended (Opoku, 2006). Similarly, Dalgleish (2003) contends the relationship between customer feedback and quality indicating the significance of feedback in hotel operations. Pillai \& Goldsmith (2006) propose that companies should lay emphasis on collecting and using customer feedback information in their improvement operations. Besides, receiving feedback from guests denotes current operational performance, service efficiency and the attitudes of the front office personnel. Heung \& Lam (2003) indicated that effective management of guest feedback could aid customer loyalty and retention. Efficient handling of feedback according to Wisner \& Corney (2001) permits hotels to evaluate and improve their services and capabilities needed for enhancing competitiveness.

Research pointed out different means of gathering feedback from customers that are available to hotels for instance; guest comment cards, inroom questionnaire, guest contact staff, telephone survey, internet survey, mail survey, and focus group interview (Birkby, 2004; Wirtz \& Tomlin, 2000). Out of these, the guest comment card has generally been used to obtain 
feedback in the hospitality industry. The positive aspect of the guest comment card is the easy assess of collecting data. In view of O'Neill (2001), guest comment card can convey a caring attitude to loyal customers as a means of building a relationship with them. In addition, questionnaires are generally used approach to determining guest satisfaction from providers end. A study conducted by Barsky (1996) suggests that, conducting a focus group interview with guests, employees, and management to ascertain the service areas that need enhancement is an alternative way of gathering feedback data. According to him, the approach provides not only problems from the guest perspective but also offer solutions to improve performance.

Jones (2004) commends the use of face-to-face interview as an appropriate feedback channel that improves service quality resulting to service excellence as it points out in-depth remarks from guests. Further, Internet technologies are also used to gather guest feedback. Equally, Sampson (1998) recommends companies to assign E-mail addresses for submitting comments and questions. In the author's view, mail surveys provide the capability to gather suitable and representative samples. In fact, guest feedback is obtainable in many forms (Sanes, 1993) and is the most valuable source of information to enhance guest satisfaction. This can serve, as an eye opener for hotels as one channel alone is not sufficient to get to customers with different culture backgrounds. Bearing this in mind, Carnell (2003) proposes that customer feedback channel should be used at where it will be effective. Using different customer feedback systems permit managers to record and report information quickly and easily. Processing data collected frequently assists management in tracking hotel service quality.

\subsection{The Hotel Industry in Ghana}

Hotels have always been an integral part of tourism efforts in Ghana. In fact, one of the first attempts made by the country at enhancing tourism was the construction of a one-star hotel in 1956, furnished with 110 rooms and provided accommodation for visitors who came to participate in Ghana's independence celebrations in 1957 (Asiedu, 1997). The hotel sector is a major earner of foreign exchange for the economy of Ghana and by 2007; it was touted to have contributed 6.3\% to our GDP (World Travel and Tourism Council, 2007). As at 2002, accommodation providers, (including hotels) accounted for $32 \%$ of the total revenue obtained from the tourism sector (Ghana Tourist Authority, 2010). Apart from its contribution to GDP, it again serves as a source of employment for many people. Due to the recent discovery of oil in Ghana, a huge number of people patronizing the hotels are requesting for service quality that can meet their expectation. For hotels to meet customer demand, the service standards set by the managers in the service industry should be the one that will conform to the expectations of customers (Tsang 
\& Qu, 2000). Therefore collecting feedback from hotel guests could assist hoteliers to strategically enhance their service delivery.

\section{Research Method}

A structured questionnaire was designed after extensive literature reviewed from earlier researchers (Ofir \& Simonson, 2001; Heung \& Lam, 2003; Heung, Kucukusta \& Ekiz, 2010). The questionnaire was organized into sections to receive information regarding, customer feedback channel available hotels, the effectiveness of customer feedback channels and feedback channels customers prefer. The first part was on the demographic data, purpose of visit and category of visitors. The second part was about the available feedback channels in the hotels. A list of different customer feedback channels was made available to guests to choose from. Also, the opportunity was given to respondents to provide feedback channels that were obtainable in the hotels but not on the list. Finally, a question was asked to determine the effectiveness of customer feedback channel as perceived by hotel guests. A-5 point scale was used to measure effectiveness (1-highly ineffective and 5 very effective). The instrument was pretested with 35 hotels guests. No problems were encountered. This confirmed the validity of the tool. The target population for this study was guests who lodged at three hotels in Ho at the time the study was conducted. The hotels involved were two-to-three star hotels and were chosen based on their preparedness to participate in the survey. Data were collected from the respondents in fourteen days. Convenience sampling approach was used to collect data. Out of the 300 questionnaires distributed, 171 questionnaires were retrieved and used for the final analyses representing $57 \%$ response rate. Descriptive analysis was used to explore the responses from the respondents. Further, T-test and analyses of variance (ANOVAs) were applied to compare means and also identify possible significance differences.

\section{Results And Discussions Demographic characteristics}

The first part of the results presents (Table 1) the demographic characteristics of the respondents. The majority of the respondents $59.6 \%$ were males. About $40.4 \%$ of them were aged between 20 and 29. The number of respondents who were Self-employed or Students was equal thus at 31.6 $\%$ each and more than half $(71.9 \%)$ of them were at the hotel for leisure. The number of first-time and repeat visitors was almost equal, at 53 and $47 \%$, respectively. 
Table 1: Demographic characteristics of respondents

\begin{tabular}{|c|c|c|c|}
\hline \multicolumn{2}{|c|}{ Study Parameters } & $\begin{array}{c}\text { Frequency } \\
(\mathbf{n = 1 7 1})\end{array}$ & $\begin{array}{c}\text { Percentage } \\
(\boldsymbol{\%})\end{array}$ \\
\hline \multirow{2}{*}{ Gender } & Female & 69 & 40.4 \\
& Male & 102 & 59.6 \\
\hline Age group (years) & $20-29$ & 69 & 40.4 \\
& $30-39$ & 42 & 24.6 \\
& $40-49$ & 42 & 24.6 \\
& $50-59$ & 3 & 1.8 \\
& $60-$ above & 15 & 8.8 \\
\hline Occupation & Self Employed & 54 & 31.6 \\
& Civil Servant & 30 & 17.5 \\
& Retired & 15 & 8.8 \\
& Unemployed & 18 & 10.5 \\
& Student & 54 & 31.6 \\
\hline Purpose of visit & Business & 48 & 28.1 \\
& Leisure & 123 & 71.9 \\
\hline Category of visitor & First-time Visitor & 90 & 52.6 \\
& Repeat Visitor & 81 & 47.4 \\
\hline
\end{tabular}

Table 2: Availability of customer feedback channel

\begin{tabular}{|c|c|c|}
\hline Rank & Feedback channel & Frequency $*$ \\
\hline 1 & Suggestion Boxes & 150 \\
\hline 2 & Telephone / Mobile & 141 \\
\hline 3 & Personal Emails & 117 \\
\hline 4 & Website & 111 \\
\hline 5 & One-On-One Contact & 105 \\
\hline 6 & Guest Comment Cards & 102 \\
\hline 6 & Social Media & 102 \\
\hline 8 & Customer Surveys / Online Surveys & 93 \\
\hline 9 & In-Room Questionnaires & 69 \\
\hline
\end{tabular}

Note $*$ Number of selection

\section{Hotel Customer Feedback Channels}

In finding out the available customer feedback channels in the Hotels, customers were asked if the hotel staff had informed them of availability of feedback channels and result showed that $60.8 \%$ responded in the affirmative whiles $39.2 \%$ responded in the negative. Lists of probable and expected feedback channels were provided to the respondents in the questionnaire and were allowed to pick more than one channel they saw in the Hotel. The results of the frequency analysis (Table 2) showed that, the most common customer feedback channels available at the hotels were suggestion boxes (150), followed by Telephone / Mobile (141), Personal Emails (117) and Website (111). 
Table 3: Perceived Effectiveness of customer Feedback Channels

\begin{tabular}{|c|c|c|c|}
\hline Rank & Feedback Channels & Mean* & Std. Deviation \\
\hline 1 & Suggestion Boxes & 3.9636 & 1.19394 \\
\hline 2 & Telephone / Mobile & 3.6842 & 1.20525 \\
\hline 3 & Personal Emails & 3.4821 & 1.29935 \\
\hline 4 & Social Media & 3.4821 & 1.16831 \\
\hline 5 & One-On-One Contact & 3.4107 & 1.36391 \\
\hline 6 & Website & 3.4035 & 1.12500 \\
\hline 7 & Guest Comment Cards & 3.2407 & 1.41775 \\
\hline 8 & In - Room Questionnaires & 3.2321 & 1.34018 \\
\hline 9 & Customer Surveys/Online Surveys & 3.0909 & 1.35619 \\
\hline \multicolumn{2}{|c|}{ Note * Mean scale: 1 - 5 (1 = highly ineffective, 5 = highly effective) }
\end{tabular}

\section{Perceptions of Effectiveness of the Channels}

After the indication of the availability of those customer feedback channels in the Hotels, respondents were entreated to express their perceptions of the effectiveness of the feedback channels available in the Hotels. Table 3 indicates the ranking of the effectiveness of customer feedback channels. The perception of the effectiveness of the channels was measured on a 5-point Likert scale, ranging from $1=$ highly ineffective to $5=$ highly effective. Results showed that Suggestion Box (mean score $=3.9636$ ) was found be the most effective feedback channel, followed by Telephone / Mobile (mean score $=3.6842$ ) and Personal Emails (mean score = 3.4821).

\section{Table 4: Effective Communication on feedback to customers}

\begin{tabular}{|c|c|c|c|}
\hline \multicolumn{2}{|c|}{ Study Parameters } & Frequency & Percentage (\%) \\
\hline $\begin{array}{c}\text { Have you ever been contacted by hotel on the } \\
\text { basis of the feedback you provided } \\
(\mathrm{n}=168)\end{array}$ & $\begin{array}{c}\text { Yes } \\
\text { No }\end{array}$ & 69 & 41.1 \\
\hline $\begin{array}{c}\text { If yes, were you satisfied with their response } \\
\text { to your feedback? } \\
(\mathrm{n}=69)\end{array}$ & Yes & 59 & 58.9 \\
\hline $\begin{array}{c}\text { If yes, do you believed your feedback help in } \\
\text { improving their services? } \\
(\mathrm{n}=54)\end{array}$ & Yes & 54 & 78.3 \\
\hline
\end{tabular}

Results discover that out of the 168 respondents, only 69 of the respondents representing $41.1 \%$ were contacted by hotel managers on the feedback they provided. The remaining $58.9 \%$ being the majority were not contacted. Out of the 69 contacted, $78.3 \%$ were satisfied with responses on their feedback and with this, $78.3 \%$ believed their feedback help in improving the services of the hotel as shown in Table 4. This implies should managers contact customers on the feedback they provide, services of the hotels will be improved drastically since it makes the customer feels as part of the institution. 
Table 5: Preferred customer feedback channels

\begin{tabular}{|c|c|c|}
\hline Rank & Feedback channel & Frequency ${ }^{*}$ \\
\hline 1 & One-On-One Contact & 45 \\
\hline 2 & Telephone / Mobile & 36 \\
\hline 3 & Guest Comment Cards & 24 \\
\hline 4 & Suggestion Boxes & 18 \\
\hline 5 & In - Room Questionnaires & 15 \\
\hline 6 & Website & 12 \\
\hline 7 & Personal Emails & 9 \\
\hline 8 & Customer Surveys/Online Surveys & 6 \\
\hline 9 & Social Media & 3 \\
\hline
\end{tabular}

Note $*$ Number of selections

\section{Preferred Feedback Channels}

Respondents were also asked about their preferred feedback channels in order to express their satisfaction or dissatisfaction with the hotel services. The frequency analysis (Table 5) showed that "One-On-One Contact" (45) ranked first among other feedback channels, followed by "Telephone / Mobile (36) and "Guest Comment Cards" (24). Respondents preferred One-On-One Contact to other forms of feedback channels to express their satisfaction or dissatisfaction. The reason being that it enables an effective response to their request, convenience and proper understanding of issues.

Table 6: Perceived Benefits hotels derived from customer feedback

\begin{tabular}{|c|l|c|c|}
\hline Rank & \multicolumn{1}{|c|}{ Statement } & Mean* & Std. Deviation \\
\hline 1 & It can help improve customer retention and loyalty & 4.1404 & 0.86986 \\
\hline 2 & $\begin{array}{l}\text { It delivers tangible data that can be used to make better } \\
\text { decisions }\end{array}$ & 4.0714 & 1.11909 \\
\hline 3 & Identification of customer needs and wants & 4.0351 & 1.15756 \\
\hline 4 & It can help improve products or services & 4.0000 & 1.41844 \\
\hline 5 & $\begin{array}{l}\text { It provides actionable insight to create a better customer } \\
\text { experience }\end{array}$ & 3.9474 & 1.01901 \\
\hline 6 & It can be used to identify customer advocates & 3.8421 & 1.13950 \\
\hline 7 & It offers the best way to measure customer satisfaction & 3.8246 & 1.17508 \\
\hline 8 & Helps in effective customer survey design & 3.8070 & 0.98408 \\
\hline
\end{tabular}

Note $*$ Mean scale: $1-5(1=$ strongly disagree, $5=$ strongly agree $)$

\section{Perceived Benefits hotels derived from customer feedback}

Respondents were requested to indicate their level of agreement or disagreement to how customer feedback benefits the hotels. Their opinions on the provided statement were measured on a 5-point Likert scale, ranging from $1=$ strongly disagree to $5=$ strongly agree. Results revealed that customers strongly agree that feedback helps to improve customer retention and loyalty 
(mean score $=4.1404$ ) and that it delivers tangible data that can be used to make better decisions (mean score $=4.0714$ ) which intend helps in identification of customer needs and wants (mean score $=4.0351$ ) and to help improve products and services at the hotels (mean score $=4.0000$ ). Table 6 indicates the ranking of the benefits of customer feedback channels.

\section{Significant Differences Between Demographic Variables and Effectiveness of Feedback Channels}

To define the possible significant differences between demographic variables and customer feedback channels, T-tests and one-way ANOVA were conducted. Table 7 shows that, perceptions of the feedback channel effectiveness differ significantly among the gender $(p \leq 0.05)$ as females (mean score $=3.4286$ ) perceive customer surveys/online surveys as a more effective channel than the males (mean score $=2.8824$; $\mathrm{F}$ ratio $=6.531, \mathrm{p}=$ 0.012 ) but the outcomes did not indicate significant differences among other customer feedback channels.

Additional ANOVA test was engaged in comparing the means of the effectiveness of the customer feedback channels with customers' age. Significant differences exist among different age groups (Table 8). For example customers who were in the age group $50-59$ (mean score $=5.000$ ), $20-29$ (mean score $=3.7826$ ) and $30-39$ (mean score $=3.5000)$ perceive Social Media as more effective than the age group $40-49$ (mean score $=$ 3.1429 ) and $60-$ above (mean score $=2.5000 ; \mathrm{F}$ ratio $=6.073, \mathrm{p}=0.000$ ). There are also significant differences between age groups on personal e-mails. The age group $50-59$ (mean score $=5.000)$ perceives personal e-mails as the most effective feedback channel compared to the other age groups, 30 - 39 (mean score $=3.7857$ ) and 60 - above (mean score $=3.000 ; \mathrm{F}$ ratio $=3.305, \mathrm{p}$ $=0.012$ ). Results did not indicate significant differences among other guest feedback channels

Table 7: One-Way ANOVA Results on customer Feedback Channels with gender

\begin{tabular}{|c|c|c|c|c|}
\hline & \multicolumn{2}{|c|}{ Mean values* } & \multirow[b]{2}{*}{$F$ Ratio } & \multirow[b]{2}{*}{ F Probability } \\
\hline & Female & Male & & \\
\hline Guest Comment Cards & 3.4348 & 3.0968 & 2.269 & 0.134 \\
\hline One-On-One Contact & 3.3182 & 3.4706 & 0.499 & 0.481 \\
\hline In - Room Questionnaires & 3.4348 & 3.0909 & 2.704 & 0.102 \\
\hline $\begin{array}{c}\text { Customer Surveys/Online } \\
\text { Surveys }\end{array}$ & 3.4286 & 2.8824 & 6.531 & $0.012^{\bullet}$ \\
\hline Telephone / Mobile & 3.6957 & 3.6765 & 0.010 & 0.919 \\
\hline Social Media & 3.5652 & 3.4242 & 0.591 & 0.443 \\
\hline Website & 3.5652 & 3.2941 & 2.410 & 0.122 \\
\hline Personal Emails & 3.6522 & 3.3636 & 2.017 & 0.157 \\
\hline Suggestion Boxes & 3.9545 & 3.9697 & 0.006 & 0.937 \\
\hline
\end{tabular}

Note $*$ Mean scale: $1-5(1=$ highly ineffective, $5=$ highly effective $) \cdot{ }^{\bullet} p \leq$ 0.05 
Table 8: One-Way ANOVA Results on customer Feedback Channels with age

\begin{tabular}{|c|c|c|c|c|c|c|c|}
\hline & \multicolumn{5}{|c|}{ Mean values* } & \multirow[b]{2}{*}{$\begin{array}{c}F \\
\text { Ratio }\end{array}$} & \multirow[b]{2}{*}{$\begin{array}{c}\text { F } \\
\text { Probability }\end{array}$} \\
\hline & $\begin{array}{c}20- \\
29\end{array}$ & $30-39$ & $40-49$ & $50-59$ & $\begin{array}{c}60- \\
\text { above }\end{array}$ & & \\
\hline $\begin{array}{c}\text { Guest Comment } \\
\text { Cards }\end{array}$ & 3.2273 & 3.3571 & 3.4615 & 2.0000 & 2.5000 & 1.733 & 0.145 \\
\hline $\begin{array}{c}\text { One-On-One } \\
\text { Contact }\end{array}$ & 3.1364 & 3.6429 & 3.5714 & 5.0000 & 3.2000 & 2.294 & 0.062 \\
\hline $\begin{array}{c}\text { In - Room } \\
\text { Questionnaires }\end{array}$ & 3.1739 & 3.3846 & 3.2143 & 5.0000 & 2.8000 & 1.895 & 0.114 \\
\hline $\begin{array}{l}\text { Customer } \\
\text { Surveys/Online } \\
\text { Surveys }\end{array}$ & 3.1429 & 3.1429 & 2.7857 & 5.0000 & 3.2000 & 2.138 & 0.078 \\
\hline $\begin{array}{c}\text { Telephone / } \\
\text { Mobile }\end{array}$ & 3.5652 & 3.7857 & 3.7143 & 5.0000 & 3.6000 & 1.166 & 0.328 \\
\hline Social Media & 3.7826 & 3.5000 & 3.1429 & 5.0000 & 2.5000 & 6.073 & $0.000^{\bullet}$ \\
\hline Website & 3.4348 & 3.5000 & 3.2143 & 5.0000 & 3.2000 & 2.072 & 0.087 \\
\hline Personal Emails & 3.5652 & 3.7857 & 3.0769 & 5.0000 & 3.0000 & 3.305 & $0.012^{\bullet}$ \\
\hline $\begin{array}{l}\text { Suggestion } \\
\text { Boxes }\end{array}$ & 3.9048 & 4.1429 & 3.9286 & 5.0000 & 3.6000 & 1.203 & 0.312 \\
\hline
\end{tabular}

Note $*$ Mean scale: $1-5(1=$ highly ineffective, $5=$ highly effective $) . \bullet p \leq$ 0.05

A further ANOVA test was employed to compare the means of the effectiveness of the guest feedback channels with guests' occupations. Table 9 shows the significant differences between different occupational groups.

The respondents under unemployed (mean score $=4.0000)$, Civil Servant (mean score $=3.5000)$ followed by self-employed (mean score $=3.4444$ ) perceived Guest Comment Cards to be effective than Student (mean score = 2.8824 ) and Retired (mean score $=2.4000 ; \mathrm{F}$ ratio $=4.215, \mathrm{p}=0.003$ ). There were also significant differences between occupations on One-On-One Contact as self-employed (mean score $=3.7778$ ) followed by Civil Servant (mean score $=3.7000)$ and unemployed (mean score $=3.6667)$ perceive OneOn-One Contact to be more effective than those on retirement (mean score $=$ 3.2000) and Student (mean score $=2.8235 ; \mathrm{F}$ ratio $=4.230, \mathrm{p}=0.003$ ).

Again self-employed (mean score $=3.6111$ ) and unemployed (mean score $=$ 3.5000) perceived In - Room Questionnaires to be most effective than students (mean score $=2.8333 ; \mathrm{F}$ ratio $=2.835, \mathrm{p}=0.026)$ and lastly Retired (mean score $=3.8000)$ and unemployed (mean score $=3.6667)$ respondents perceive Website to be more effective than Civil Servant (mean score $=2.9000 ;$ F ratio $=2.975, \mathrm{p}=0.021$ ). Results did not indicate significant differences among other guest feedback channels 
Table 9: One-Way ANOVA Results on customer Feedback Channels with occupation

\begin{tabular}{|c|c|c|c|c|c|c|c|}
\hline & \multicolumn{6}{|c|}{ Mean values* } & Self \\
\cline { 2 - 7 } & $\begin{array}{c}\text { Self } \\
\text { Employed }\end{array}$ & $\begin{array}{c}\text { Civil } \\
\text { Servant }\end{array}$ & Retired & Unemployed & Student & $\begin{array}{c}\text { F } \\
\text { Ratio }\end{array}$ & $\begin{array}{c}\text { F } \\
\text { Probability }\end{array}$ \\
\hline $\begin{array}{c}\text { Guest Comment } \\
\text { Cards }\end{array}$ & 3.4444 & 3.5000 & 2.4000 & 4.0000 & 2.8824 & 4.215 & $0.003^{\bullet}$ \\
\hline $\begin{array}{c}\text { One-On-One } \\
\text { Contact }\end{array}$ & 3.7778 & 3.7000 & 3.2000 & 3.6667 & 2.8235 & 4.230 & $0.003^{\bullet}$ \\
\hline $\begin{array}{c}\text { In - Room } \\
\text { Questionnaires }\end{array}$ & 3.6111 & 3.0000 & 3.4000 & 3.5000 & 2.8333 & 2.835 & $0.026^{\bullet}$ \\
\hline $\begin{array}{c}\text { Customer } \\
\text { Surveys/Online } \\
\text { Surveys }\end{array}$ & 3.1176 & 2.7000 & 3.6000 & 3.3333 & 3.0588 & 1.318 & 0.266 \\
\hline Telephone / Mobile & 3.9444 & 3.8000 & 3.8000 & 3.5000 & 3.3889 & 1.675 & 0.158 \\
\hline Social Media & 3.5556 & 3.2000 & 3.0000 & 3.6000 & 3.6667 & 1.523 & 0.198 \\
\hline Website & 3.6111 & 2.9000 & 3.8000 & 3.6667 & 3.2778 & 2.975 & $0.021^{\bullet}$ \\
\hline Personal Emails & 3.6667 & 3.1111 & 3.8000 & 3.8333 & 3.2778 & 1.740 & 0.144 \\
\hline Suggestion Boxes & 4.1667 & 3.5000 & 3.8000 & 4.3333 & 3.9375 & 2.083 & 0.086 \\
\hline
\end{tabular}

Note. ${ }^{*}$ Mean scale: $1-5(1=$ highly ineffective, $5=$ highly effective $) .{ }^{\bullet} p \leq$ 0.05

T-tests were also performed to compare the means of the groups of purposes of the visit and category of visitors with the perception of effective feedback channels. The results show significant differences between purposes of the visit as in business and leisure. The results reveal that their perceptions differ significantly with regard to One-On-One Contact $(\mathrm{p}=0.041)$, Customer Surveys/Online Surveys $(\mathrm{p}=0.038)$, Telephone / Mobile $(\mathrm{p}=0.032)$, and Website $(\mathrm{p}=0.011)$. With the exception of Customer Surveys/Online Surveys business visitors perceived those channels as more effective than the leisure visitors and recorded higher mean scores (Table 10). However, business customers might find these channels effective because they serve as a catalyst to speed their transactions.

Table 10: Independent Samples T-Test Results Between Purposes of the visit and Customer Feedback Channels

\begin{tabular}{|c|c|c|c|c|}
\hline \multicolumn{5}{|c|}{ Mean values* } \\
\hline & Business & Leisure & t Value & Two-Tailed Sig. \\
\hline Guest Comment Cards & 3.3333 & 3.2051 & 0.514 & 0.608 \\
\hline One-On-One Contact & 3.7500 & 3.2750 & 2.059 & $0.041^{\bullet}$ \\
\hline In - Room Questionnaires & 3.2000 & 3.2439 & -0.187 & 0.852 \\
\hline Customer Surveys/Online Surveys & 2.7500 & 3.2308 & -2.089 & $0.038^{\bullet}$ \\
\hline Telephone / Mobile & 4.0000 & 3.5610 & 2.163 & $0.032^{\bullet}$ \\
\hline Social Media & 3.5000 & 3.4750 & 0.125 & 0.901 \\
\hline Website & 3.7500 & 3.2683 & 2.557 & $0.011^{\bullet}$ \\
\hline Personal Emails & 3.6667 & 3.4146 & 1.114 & 0.267 \\
\hline Suggestion Boxes & 4.1250 & 3.8974 & 1.113 & 0.267 \\
\hline
\end{tabular}

Note. * Mean scale: $1-5(1=$ highly ineffective, $5=$ highly effective $)$.

$$
\bullet p \leq 0.05 \text { (two-tailed) }
$$


T-test analysis conducted on perceptions of customer' feedback effectiveness and category of visitors as shown in (Table 11) reveals that, the only significant difference between a First-time visitor and Repeat visitor occurred in the perception of the Telephone/Mobile contact.

Table 11: Independent Samples T-Test Results Between Category of Visitors and Customer Feedback Channels

\begin{tabular}{|c|c|c|c|c|}
\hline & \multicolumn{2}{|c|}{ Mean values* } & \multirow{2}{*}{ t Value } & $\begin{array}{c}\text { Two-Tailed } \\
\text { Sig. }\end{array}$ \\
\cline { 2 - 3 } & $\begin{array}{c}\text { First-time } \\
\text { Visitor }\end{array}$ & $\begin{array}{c}\text { Repeat } \\
\text { Visitor }\end{array}$ & & 0.995 \\
\hline Guest Comment Cards & 3.2414 & 3.2400 & 0.006 & 0.518 \\
\hline One-On-One Contact & 3.3448 & 3.4815 & -0.648 & 0.551 \\
\hline In - Room Questionnaires & 3.1724 & 3.2963 & -0.598 & 0.223 \\
\hline $\begin{array}{c}\text { Customer Surveys/Online } \\
\text { Surveys }\end{array}$ & 2.9643 & 3.2222 & -1.223 & \\
\hline Telephone / Mobile & 3.5000 & 3.8889 & -2.129 & $0.035^{\bullet}$ \\
\hline Social Media & 3.5172 & 3.4444 & 0.403 & 0.688 \\
\hline Website & 3.3000 & 3.5185 & -1.271 & 0.206 \\
\hline Personal Emails & 3.5667 & 3.3846 & 0.905 & 0.367 \\
\hline Suggestion Boxes & 3.7857 & 4.1481 & -1.966 & 0.051 \\
\hline
\end{tabular}

Note. ${ }^{*}$ Mean scale: $1-5(1=$ highly ineffective, $5=$ highly effective $)$.

$$
\bullet p \leq 0.05 \text { (two-tailed) }
$$

\section{Conclusion}

The results of the study revealed that suggestion box is mostly used as customer feedback channel by hotels followed by telephone/mobile phone. It demonstrates that perhaps guests do not want to expose their identity in relation to comments they provide to hotels. Similar work done by Heung, Kucukusta \& Ekiz (2010) revealed that hotels in China commonly used guest comment cards as means of getting feedback from customers. In determining the effectiveness of customer feedback channels in the hotel, customers rank again suggestion box as a most effective channel among all feedback channels indicating the significance of providing suggestion boxes at vantage points for easy access to guests. Moreover, respondents believed their feedback assisted in improving the services of the hotels. This implies that hotel managers should contact customers on the feedback they provide as a means of improving hotel services. Again respondents were asked to indicate their preferred feedback channel to express their satisfaction and dissatisfaction with hotel services. One-on-one contact was ranked first among all other channels followed by telephone/mobile phone.

Also, significant differences in guests' perceptions of effective feedback channels were found between gender, age group, purpose and occupation. Feedback channels effectiveness differ significantly among the gender $(\mathrm{p} \leq 0.05)$, as females perceive customer survey/online survey as more 
effective channel than the males. Age group also shows significant differences as regards feedback channels. For example, customers who were in the age group 50 - 59, 20 - 29 and $30-39$ perceived Social Media as more effective than the age group $40-49$ and 60 - above. There are also significant differences between age groups on personal e-mails. The age group $50-59$ perceives personal e-mails as the most effective feedback channel as compare to the other age groups, 30 - 39 and 60 years and above.

Previous work done by Heung, Kucukusta \& Ekiz (2010) in China also recorded significant differences in guests' perceptions on effective feedback channels between age groups, the purpose of visit, occupation, and origin of the guests. Evidently, the result of this study is an indication that demographic characteristics of guests influence their perceptions of effective feedback channels. Therefore it stands to reason that hotel managers should develop effective customer feedback systems in relation to guest's profile. A deduction from this study is that customers strongly agree that feedback helps to improve customer retention and loyalty and that it delivers tangible data that can be used to make better decisions. It again contributes to the identification of customer needs and wants.

Further tests were performed to compare the means of the groups on purposes of the visit and category of visitors with the perception of effective feedback channels. The results show significant differences between purposes of the visit as in business and leisure. The results indicated that their perceptions differ significantly with regard to One-On-One Contact, Customer Surveys/Online Survey, Telephone / Mobile and Website. With the exception of Customer Surveys/Online Surveys business visitors perceived those channels as more effective than the leisure visitors. However, business customers might find these channels effective because they serve as a catalyst to speed their transactions. Since leisure visitors have more time to relax at the hotels, they might prefer to communicate with management to express their views about their satisfaction or dissatisfaction. An additional test was employed to compare the means of the effectiveness of the guest feedback channels with guests' occupation. The result shows that unemployed, civil servant and self-employed perceived guest comment cards to be effective. This might be for convenience, because comment cards can easily be located in the guest rooms or on dining tables in the restaurants. In relation to occupation, business visitors prefer one-on-one contact, Telephone/Mobile, and Website feedback channels to others.

The findings of the study disclosed important implications to hotel managers in Ho, Ghana. Firstly, the study emphasizes the importance of collecting feedback from customers in hotels. Hotel Managers in Ho, Ghana should consider demographic characteristics when designing customer feedback systems. It is also important for hotels to train their employees to 
handle customer feedback effectively. Secondly, Managers should endeavor to identify customer feedback channel guests preferred most so that guests would be eager to provide the necessary information needed to improve performance. Providing multiple channels could allow guests to make the best choice to give out information about their satisfaction or dissatisfaction on products or services. The limitation of the study is that only three hotels in Ho willingly took part in the survey. Care must be taken in generalizing the results to any other countries. Future research may extend to other regions for generalization.

\section{References:}

Ackley, H. (2007). From Strategic Planning to Everyday Practice - Customer Orientation in Nordic Road Administrations. Downloaded from the wwwpage of PIARC at: http://publications.piarc.org/ressources/publications_files/4/1856,RR334026.pdf. (Accessed 23/6/2010).

Asiedu, A. B. (1997). Prospects for an Emerging Tourism Industry in Ghana. Research Review (NS), 13 (1\&2), 14-15.

Babbar, S. \& Koufteros, X. (2008). "The human element in airline service quality: contact personnel and the customer", International Journal of Operations \& Production Management, 28 (9), 804-830.

Barsky, J. (1996). Designing services with function analysis. The Hospitality Research Journal, 20(1), 73-100.

Berry, L.L. \& Parasuraman, A. (1997), "Listening to the customer \pm the concept of a service-quality information system", Sloan Management Review, Spring, pp. 65-76.

Birkby, B. (2004). Standing in the customers' shoes. The British Journal of Administrative Management, 41, 26-28.

Bitner, J. M. Booms, B. H. \& Mohr, J. (1994). “Critical service encounters: the employees viewpoint". Journal of Marketing, 58 (4), 95-106.

Carnell, M. (2003). Gathering customer feedback. Quality Progress, 36 (1), 60-61.

Chase, R. B., and R. H. Hayes. 1991. Beefing up operations in service firms. Sloan Management Review 33 (1), 15-26.

Chisholm, J. (2005). Six things every CEO should know about using guest feedback to build loyalty and profit. Retrieved November 15, 2008, from http://www.customersat.com/Resources/ Articles/PCEO0804.pdf

Ciotti, G. (2013). The 7 Best Ways to Gather Customer Feedback- Help Scout http://www.helpscout.net/blog/customer-feedback. (Accessed 23/6/2010).

Cole, R.E. (2001). "From continuous improvement to continuous innovation", Quality Management Journal, 8 (4). 
Dalgleish, S. D. (2003). Customer feedback is real quality certification. Quality, 42(3), 18

Day, R. L. \& Landon, E. L. (1977). "Towarda theory of consumer complaint behavior", in Woodside et al. (Eds), Consumer and Industrial Buying Behavior, North Holland, New York, NY.

Donovan, P., \& Samler, T. (1994). Delighting customers the ten-step approach to building a customer-driven organization. Managing Service Quality, 4 (6), 38-43.

Erickson, G. S. \& Eckrick, D. W. (2001). "Consumer affairs responses to unsolicited consumer compliments". Journal of Marketing Management, 7 (3). 321-340.

Fundin, A. P. \& Bergman, B. L. S. (2003)."Exploring the customer feedback process", Measuring Business Excellence, 7 (2), 55 - 65.

Ghana Tourist Board (2010). Tourism Statistical Fact sheet on Ghana. 2007, Retrieved

from:http://www.touringghana.com/documents/Facts_andFigures/Tourism_S tatistical_Fact Sheet_070316.pdf. Accessed: 11/04/2014.

Gilly, M. C., \& Hansen, R. W. (1985). Consumer complaint handling as a strategic marketingtool. Journal of Consumer Marketing, 2(4), 5-16

Graulich, D. (1991). How are you doing? Ask your clients. Business Horizons, 34 (5), 26-27.

Heung, V. C. S., \& Lam, T. (2003). Guest complaint behavior towards hotel restaurant services. International Journal of Contemporary Hospitality Management, 15 (5), 283-289.

Heng, Kucukusta \& Ekiz (2010). Evaluation of Guest Feedback Channel in China Hotels. Journal of China Tourism Research, 6 (3), 296-309.

Hoffman, K. D., \& Bateson, J. E. G. (1997). Essentials of services marketing. Fort Worth, TX: The Dryden Press.

Jones, C. R. (2004). A "scorecard" for service excellence. Measuring Business Excellence, 8(4), 45-54.

Lam, T., \& Tang, V. (2003). Recognizing demographic characteristic differences in customer complaint behavior: The case of Hong Kong hotels restaurants. Journal of Travel and Tourism Marketing, 14 (1), 69-86.

Lusch, R.F., Vargo, S.L. and O'Brien, M. (2007). "Competing through service: insights from service-dominant logic", Journal of Retailing, 83 (1), 518.

Maxham, J. G., III. (2001). Service recovery's influence on customer satisfaction, positive word-of-mouth, and purchase intentions. Journal of Business Research, 54 (1), 11-24.

Ofir, C., \& Simonson, I. (2001). In search of negative customer feedback: The effect of expecting to evaluate on satisfaction evaluations. Journal of Marketing Research, 38 (2), 170-182. 
O'Neill, M. (2001). Measuring service quality and customer satisfaction. In J. Kandampully, C. Mok, \& B. Sparks (Eds.), Service quality management in hospitality, tourism and leisure 159-192). New York: Haworth Hospitality Press.

Opoku, R. A. (2006). Gathering customer feedback online and Swedish SMEs. Management Research News, 29 (3), 106-127.

Pearson, M. M. (1976). A note on business replies to consumer letters of praise and complaint. Journal of Business Research, 4 (1), 61-68.

Pillai, K. G., \& Goldsmith, R. E. (2006). Calibrating managerial knowledge of customer feed- back measures: A conceptual model. Marketing Theory, 6 (2), 223-243.

Sampson, S. E. (1998). Gathering customer feedback via the Internet: Instruments and prospects. Industrial Management and Data Systems, 98 (2), 71-82.

Sanes, C. (1993). Complaints are hidden treasure. Journal for Quality and Participation, 16 (5), 78-82.

Smith, C., \& Jenner, P. (1998). Tourism and the Internet. Travel and Tourism Analyst, 1, 62-81.

Sujithamrak, S., \& Lam, T. (2005). Relationship between customer complaint behavior and demographic characteristics: A study of hotel restaurants' patrons. Asia Pacific Journal of Tourism Research, 10 (3), 289-307.

Tsang, N., \& Qu, H. (2000). Service quality in China's hotel industry: A perspective from tourists and hotel managers. International Journal of Contemporary Hospitality Management, 12 (5), 316-325.

Wirtz, J., \& Tomlin, M. (2000). Institutionalising customer-driven learning through fully integrated customer feedback systems. Managing Service Quality, 10 (4), 205-214.

Wirtz, J., Tambyah, S. K. \& Mattila, A. S. (2010). "Organizational learning from customer feedback received by service employees - a social capital perspective”. Journal of Service Management, 21 (3), 363-387.

Wisner, J. D. \& W. J. Corney, W. J. (2001). Comparing practices for capturing bank customer feedback: Internet versus traditional banking. Benchmarking: An International Journal, 10 (3), 240-250.

World Travel and Tourism Council. (2007). Progress and Priorities Report

Wyse, S. E. (2015). Reasons why Feedback is important http://www.snapsurveys.com/blog/5-reasons-feedback-important, (Accessed 10 December 2015). 